\title{
Measuring financial performance using new liquidity indices
}

\author{
Fatemeh Sharifi ${ }^{*}$ and Elham Taghipour
}

Department of Management and Accounting, Kashan Branch, Islamic Azad University, Kashan, Iran

\begin{tabular}{l}
\hline C H R O N I C L E \\
\hline Article history: \\
Received March 22014 \\
Accepted 29 July 2014 \\
Available online \\
August 2014 \\
\hline Keywords: \\
New liquidity indices \\
Comprehensive liquidity index \\
Cash conversion cycle index \\
Net liquidity balance index \\
Financial performance
\end{tabular}

\section{A B S T R A C T}

\begin{abstract}
Performance measurement has been considered as one of the most important subjects in accounting through separating management from ownership as well as emergence of the agency theory. The purpose of this paper is to investigate the role of new liquidity indices in evaluating of the financial performance. In the direction of realizing the research's purposes, 4 hypotheses examine the relationships between new liquidity indices and firm's financial performance. Using some linear regression techniques with some panel data, the study examines various hypotheses of this survey. The research's statistical sample includes 67 firms over the period 2006-2011. Analysis of the hypotheses shows that hypotheses associated with comprehensive liquidity index have been supported. In addition, there are significant differences in financial performance in different industries.
\end{abstract}

(C) 2014 Growing Science Ltd. All rights reserved.

\section{Introduction}

Measuring financial performance of big corporations has been controversial issues among different parties including shareholders, management team, etc. Stockholders care about the amount of wealth increase either through increasing the price or cash profit or through cash benefit. Managers consider these evaluations for evaluating their performances and the fee paid to them. However, inverters' view is the most important. This social stratum is not normally willing to invest in the high risk companies and if they do, more return will be expected in lieu to more value. Assets return and the return on equity evaluating is one of the used standards used from 1980s. The ratio of Tobin's Q is other important standards for evaluating the performance of companies. This standard has been proposed in 1970s and has widely been used by researchers (Asqari \& Malekian, 2006). In addition, the performance evaluation is identified by two indices of liquidity power and profitability. Profitability shows the correctness of economic enterprise, and the liquidity power is the viability of the economic enterprise. Although both of them are important, the liquidity is more important. Any firm with low profitability or even non- profitability can stay on the business longer than a company with no liquidity (Talebi, 1995). Indices evaluated the liquidity condition of firm have been attended by analysts from a long time. This issue causes analysts to present new indices by analyzing the *Corresponding author.

E-mail addresses: fshadi33@yahoo.com (F. Sharifi) 
defects of traditional indices (Khoshtinat \& Namazi, 2004). The new indices include comprehensive liquidity index, cash conversion cycle index, net liquidity balance index. These indices try to consider the defects resulting from traditional indices of liquidity that these defects occur because of not considering the details of firm's liquidity condition. According to close relation between liquidity condition of firms and their financial performance in this research, the role of new indices of liquidity in evaluating financial performance of firms is investigated. There are some new definitions for liquidity as follows,

Comprehensive liquidity index: it eliminates the problem related to not considering the rate of liquidity of current assets and the time of debt payback by calculating the weighted average current ratio (Melyk \& Birita, 1974).

Cash conversion cycle index: cash conversion cycle is the net interval cycle between paying back debts and receiving cash from the place of debt collection. The firm shows a better liquidity whatever this cycle is shorter (Gitman, 1974).

Net liquidity balance index: in this index, cash balance and stocks are attended to show the condition of firm liquidity. This index shows the store of the real liquidity of the firm in association with nonpredictable needs (Shulman \& Cox, 1985).

Some researchers compared the relationship between traditional indices and new indices of liquidity in the Tehran Stock Exchange for auto industry. This research was carried out by using traditional and new indices of liquidity over the period 2004-2009, and the result showed there were a positive correlation between traditional ratio and new indices of liquidity. All standard proposed in their researches were suitable for evaluating the liquidity in the framework of its assumptions and each of them considered one dimension of liquidity issue. Khani and Haqiqi (2012) evaluated the increasing and relative content of information of internal return rate based on the cash recovery to the rate of assets return in firms accepted in Tehran stock exchange. In this research, both the index of stock return rate and ratio of Tobin's $Q$ were used as basic indices, and the amounts of explaining these two basic indices were tested by indices of internal return rate based on cycling cash and assets return by using multivariable regression. The result showed that internal return rate based on cash cycling had a relative and increasing informative content than assets return rate. Wang (2002) studied a relationship of liquidity management and profitability and firm value of a 1555 Japan firms and 375 Taiwan firms over the period 1996-1985. The result of his research showed there were negative and significant relationship between cash converting cycle and indices of profitability. Additional to this daringly, liquidity management occurred by reducing the cash conversing cycle caused to improve the firm performance, finally increasing the firm value.

Nobanee and AlHajjar (2009) investigated the relationship between managing the turnover capital, firm performance and activating the cash turnover of 5802 firms over the period 1990-2004. The results showed that manager could increase profitability and cash turnover of firm by decreasing the cash conversion cycle and the receipt of receivable account. In addition, decreasing the stock conversion cycle and increasing the account payable due date cycle could lead to decrease the profitability and cash turnover of firm. Yalcin et al. (2012) proposed a new financial performance evaluation approach to rank the companies of each sector for some Turkish manufacturing firms. For this purpose, a hierarchical financial performance evaluation model was structured based on the AFP and VFP main-criteria and their sub-criteria. They used fuzzy analytic hierarchy process (FAHP) to determine the weights of the criteria. The companies were ranked according to their own manufacturing sector by using two multi criteria decision making techniques named TOPSIS and VIKOR, comparatively. The results showed that the obtained ranks of the companies by these methods were almost the same compared with their own sectors. 


\section{The proposed study}

The Main hypothesis: There is a relationship between new indices of liquidity and financial performance of manufacturing firm accepted in Tehran Stock Exchange. There are also four subhypothesis as follows,

1 - There is a relationship between cash conversion cycle index and financial performance.

2 - There is a relationship between net liquidity balance index and financial performance.

3 - There is a relationship between comprehensive liquidity index and financial performance.

4- Financial performances of manufacturing firms of different industries differ from each other on the basis of new indices of liquidity.

The manufacturing firms accepted in Tehran Stock Exchange during 2006-2011 were the statistical society of this research by considering some specific characteristics. First, they must be profitable, they all must have the same fiscal calendar ending March, no banks, holding or financial institution was permitted in the survey. In addition, they should have had any change on their fiscal year, all information must be available and there must be no interruption on financial and trading activities. In this research, randomly sample size is obtained by the Cochran formulation and 67 firms were needed in this research as statistical sample. The number of firms was randomly selected among firms become members of Tehran Stock Exchange and they were placed in form of 8 industries including chemical, medicinal, cement-gypsum-lime, manufacturing automobiles and parts, basic metals, foodstuffs, non- metal minerals, machineries and equipment. Since all firms of statistical society had the same opportunity to select and our purpose was to generalize the results, the method of randomly simple sampling has been used. According to kind of data and available analytic method in this research, panel data has been used, because relation of liquidity indices and financial performance of firms, dependent and independent variables are investigated, differently. These variables were tested among various firms and in a 6-year period. To estimate the regression model related to combined data, one of methods of common effects, fixed effects, and random effects was used. In this research, results obtained by using the distinguishing Lymer's F test and Hausman's test showed the priority of using the random effects method for estimating all regression models in comparison with fixed effects method. Because of non-static nature of most economic variables in level, estimating econometrics patterns in time interval by these variables may lead to a false regression. Therefore, using economic variables in econometrics patterns are dependent on performing reliable test. In this research, the unit root and Dickey Fuller tests have been used to determine the reliability of the model variables. To carry out the statistical tests, SPSS 16, Eviews 7 software have been used to analyze the data. The study considers a regression model in form of $y_{i}=f\left(x_{1}, x_{2}, x_{3}\right), i=1,2,3$ where independent variables are new indices of liquidity and dependent variable is financial performance. In other words, $y_{1}$ is ratio of return of equity, $y_{2}$ is the asset return ratio and $y_{3}$ is Tobin's Q ratio. In addition, $x_{1}$ is the net liquidity balance index, $x_{2}$ is the cash conversion cycle index and $x_{3}$ is the comprehensive liquidity index. Let $x_{1}: N L B=(C A S H+M K T-A P) / T A$ where $\mathrm{NLB}=$ net cash balanced, $\mathrm{CASH}=$ cash, $\mathrm{MKT}=$ sellable stock, $\mathrm{AP}=$ payable document, $\mathrm{TA}=$ total assets. In addition, $x_{2}: C C C=O C-P P, O C=I N V P+R P$, and $P P=P A / D C O G S$ where $C C C=$ the cash conversion cycle, $O C=$ operational cycle, $P R=$ the cycle of debt collection, $I N V P=$ the cycle of keeping goods inventory, $P A=$ balance account payable and $D C O G S=$ cost of daily goods sold. $x_{3}: A C R=A C A / L C A$ where $A C R, A C A$ and $L C A$ are comprehensive liquidity index, adjusted current asset and adjusted current debt, respectively. For all relationships, we consider $y_{i}=\alpha+\beta_{1} x_{1}+\beta_{2} x_{2}+\beta_{3} x_{3}+\varepsilon$.

\section{The Results}

To test the research's hypothesis, first, variables normality is investigated by Kolmogorov-Smirnov test. According to Table 1, the assumption of normality of variable of return of equity is supported. 
However, the assumption of normality of variable of asset return and Tobin's Q ratio is supported after performing the logarithm.

\section{Table 1}

The results of Kolmogorov- Smirnov test

\begin{tabular}{lllll}
\hline Variable & $\begin{array}{l}\text { Statistics of } \\
\text { Kolmogorov- Smirnov }\end{array}$ & Significance level & $\begin{array}{l}\text { Statistical result after } \\
\text { performing logarithm }\end{array}$ & Significance level \\
\hline Return on equity & 0.934 & 0.347 & & 0.149 \\
Return on asset & 2.457 & 0.000 & 1.140 & 0.228 \\
Tobin's Q ratio & 2.973 & 0.000 & 1.042 & \\
\hline
\end{tabular}

Then reliability of dependent and independent variables is investigated. According to unit root test for variables whose P-Value amount is lower than 0.05 , they are reliable during the research. The results are shown in Table 2.

Table 2

Testing the reliability of research variables

\begin{tabular}{lll}
\hline Variables & Statistics of Dickey Fuller & Significance level \\
\hline Return on equity & -20.024 & 0.000 \\
logarithm return on asset & -8.4818 & 0.000 \\
logarithm Tobin's Q & -5.7629 & 0.000 \\
\hline
\end{tabular}

Table 3

The statistic of Durbin-Watson and F- statistics

\begin{tabular}{|c|c|c|c|c|}
\hline Variables & Durbin-Watson & F-value & Sig. & Determinant balance coefficient \\
\hline Return on equity & 2.399 & 0.048 & 0.986 & 0.007 \\
\hline logarithm return on assets & 0.8217 & 4.82 & 0.0026 & 0.02 \\
\hline logarithm Tobin’s Q & 0.8784 & 3.74 & 0.011 & 0.02 \\
\hline
\end{tabular}

In addition, the statistic of Durbin-Watson is used in regressive model for investigating specification error. In other word, if rest of regression shows a systematic pattern, the specification error will be existed. Additional to this $\mathrm{F}$ statistic, the multivariable regression model is used for testing significance. If calculative $\mathrm{F}$ is higher than standard amount of $\mathrm{F}$ in a specific level, the total significance of regression is accepted in level of significance. After investigating the reliability of variables, confidence of lack of continuous correlation and significance of estimated regression model for two variables (logarithm of asset return and ratio of Tobin's Q) coefficient of independent variables are calculated, as it is shown in Table 4. T statistic is used for testing significance of coefficient of model, so, if P-Value, the coefficient of dependent variable is lower than 0.05 , the significance of mentioned coefficient in the model is shown.

Table 4

The results testing the relationship between ROA Ln ROA and Tobin's Q

\begin{tabular}{|c|c|c|c|c|}
\hline Dependent variable & Independent variable & Regression coefficient & T statistic & Significance level \\
\hline \multirow{3}{*}{ Return on equity } & Cash conversion cycle & -0.0095 & -0.32 & 0.74 \\
\hline & Liquidity comprehension & -2.29 & -0.20 & 0.84 \\
\hline & Net liquidity balance & 14.99 & 0.12 & 0.89 \\
\hline \multirow[t]{3}{*}{ Logarithm on return assets } & Cash conversion cycle & -9.49 & -0.56 & 0.57 \\
\hline & Liquidity comprehension & 0.212 & 3.32 & 0.001 \\
\hline & Net liquidity balance & 0.95 & 1.41 & 0.15 \\
\hline \multirow[t]{3}{*}{ Logarithm on Tobin's Q } & Cash conversion cycle & 0.000 & -1.74 & 0.08 \\
\hline & Liquidity comprehension & 0.104 & 2.67 & 0.0077 \\
\hline & Net liquidity balance & -0.269 & -0.660 & 0.50 \\
\hline
\end{tabular}

$(R O A)=y_{2}=-2.53-9.49 x_{1}+0.21 x_{2}+0.95 x_{3}$

$(\mathrm{QTobin})=y_{3}=-0.19-0.0001 x_{1}+0.10 x_{2}-0.26 x_{3}$ 
Since there is no relationship between return on equities (ROA), Tobin-Q and new indices of liquidity, non- parametric correlation test is used for these two variables and the results are shown in Table 5-1. According to normality of three dependent variables (Return on equity, Ln Asset return, Ln Ratio of Tobin's Q) parametric correlation test is used for these three variables, its results are shown in table 5-2. In addition, Analysis of variance is used foe comparing the difference of financial performance of firms in different industries; its results are shown in Table 6.

\section{Table 5-1}

Spearman correlation coefficient among research variables

\begin{tabular}{llll}
\hline Variable & Cash conversion cycle & Liquidity comprehension & Net liquidity balance \\
\hline Return on equity & $-0.018(0.718)$ & $0.013(0.790)$ & $0.064(0.197)$ \\
Return on Assets & $0.087(0.081)$ & $0.114(0.022)$ & $0.113(0.024)$ \\
Ratio on Tobin's Q & $-0.86(0.085)$ & $0.080(0.107)$ & $-0.009(0.850)$ \\
\hline
\end{tabular}

Table 5-2

Pearson correlation coefficient among research variables

\begin{tabular}{llll}
\hline variable & Cash conversion cycle & Liquidity comprehension & Net liquidity balance \\
\hline Return on equity & $-0.124(0.013)$ & $0.118(0.018)$ & $0.033(0.510)$ \\
Ln Return on Assets & -0.076 & $0.178(0.000)$ & $0.064(0.202)$ \\
LN Ratio on Tobin's Q & $-0.097(0.052$ & $0.137(0.006)$ & $-0.025(0.615)$ \\
\hline
\end{tabular}

Table 6

The results of Analysis of Variance

\begin{tabular}{lccc}
\hline Variable & Return on equity & Return on Assets & Ratio on Tobin's Q \\
\hline F & 1.052 & 9.670 & 18.162 \\
Sig. & 0.394 & 0.000 & 0.000 \\
\hline
\end{tabular}

\section{Discussion and conclusion}

First hypothesis: according to research finding and Table 4 and 5, there is no relationship between cash conversion index and the ratio of asset return and ratio of Tobin's Q. These results are consistent with finding of Smith and Bridgeman (1997). One reason for lack of relation between cash conversion index and the ratio of asset return is that the duration of cash conversion index was one of the determinant factors of needed net liquidity. It seems that investigated firms did not have exact predictions about estimating the amount of future sell. As a result, this issue led to making conservative strategies in capital management, and lack of optimal allocation of capital to elements of cash conversion index. However, according to finding of research, there are reverse relationship between cash conversion cycle index and return on equity in 5\% level. These results are consistent with finding of Nobanee and Hajjar (2009) and Eljelly (2004).

Second hypothesis: according to the research, it is shown that there is a direct relation between net cash balance index and the ratio of assets return, but, it does not have relation to ratio of Tobin's Q. net cash balance index shows the storage of real liquidity of firm in relation to non-predictable short time commitments, because if the firm encounters the shortage of liquidity and want to resort to other current assets for help ( goods stock and financial claim), it is compelled to suffer a costs. In this method, generally, goods inventory and debt claim are not considered. Additionally, payable documents, means current debts having interest, just consider as binding debts in calculating the net cash balance index. Because of non-logical value of stock market of firms and provided false return rate for firms stock, the presence of high inflation in Iran, non-efficiency of Tehran Stock Exchange, the hypothesis related to Tobin's Q seems to be rejected. It is supported in different researches such as Nasrolahi (1992), Fadaeenejad (1995).

Third hypothesis: According to research's finding, there are positive and significant relations between comprehensive liquidity indices by the asset return logarithm and logarithm of ratio of Tobin's Q. There are direct relationship between comprehensive liquidity index and return on equity. There is no linear relationship between three independent variables, comprehensive liquidity index, cash 
conversion cycle index, net liquidity balance index, and dependent variable of return on equity in simultaneous investigation of total effect. There is a linear relationship among three independent variables, comprehensive liquidity index, cash conversion cycle index, net liquidity balance index, and the logarithm of ROA and logarithm of ratio of Tobin's Q ratio. However, the comprehensive liquidity index has a significant and positive effect on logarithm of asset return and logarithm of Tobin's Q ratio.

Forth hypothesis: financial performances of manufacturing firms of different industries differ from each other on the basis of new indices of liquidity. In this hypothesis, according to Table 5 and the comparison of financial performance ratio including the return on equity, ROA, Tobin's Q ratio in 8 industries, there are significant difference among financial performance of firms according to observed asset return ratio and Tobin's $Q$ ratio, while there are no significant difference among the ratio on equity. Analysis of research hypothesis shows that hypothesis related to comprehensive liquidity index has been supported. In addition, there is a significant difference among financial performance of manufacturing firms in 8 different industries. Generally, new indices of liquidity present an exact image of financial information to users in evaluating financial performance of firms, and it can effectively be a guide of users for making optimal decisions.

\section{References}

Asqari, G. \& Malekian, A. (2006). Relation between Economic Value Added and Rate Return Asset in Evaluating Performance of Firms Accepted in Stock Exchange. Economic Magazine, 24(33), 54-55.

Eljelly, A. M. (2004). Liquidity-profitability tradeoff: an empirical investigation in an emerging market. International Journal of Commerce and Management, 14(2), 48-61.

Fadainejad, M. (1995). Weak form test of performance of investment and Tehran Stock Exchange. Financial Research Magazines. 5-6, 3-26 [In Persian].

Gitman, L. J. (1974). Estimating corporate liquidity requirements: a simplified approach. Financial Review, 9(1), 79-88.

Khani, E., Haghighi, M. (2012). Increasing and proportional concepts of data about internal rate return based on cash recovery to rate return assets in firms accepted in Tehran stock Exchange. Accounting Knowledge Magazine, 3(10), 71-92.

Khoshtinat, M., \& Namazi, Z. (2004). Correlation of new and traditional cash indices. Accounting Studying Periodical, 7, 55-76.

Melyk, L. Z., \& Birita. (1974). Comprehensive liquidity index as a measure of corporate liquidity. Scientific and Behavioral Foundation of decision sciences. (Atlanta), 162-165.

Nasroallahi, Z. (1992). Analysis Performance of Stock Exchange in Iran . Thesis of Economic M.A. Teacher Training University.

Nobanee, H., \& AlHajjar, M. (2009). Working Capital Management, Operating Cash Flow and Corporate Performance. SSRN: 1471236.

Shulman, J. M., \& Cox, R. A. (1985). An integrative approach to working capital management. Journal of Cash Management, 5(6), 64-68.

Smith, M. B., \& Begemann, E. (1997). Measuring association between working capital and return on investment. South African Journal of Business Management, 28(1), 1-4.

Taleb Bidekhti, A., \& Faraji, F. (2011). Comparable examination between new and traditional cash indices in Tehran Stock Exchange -Automobile industry. Financial Knowledge of Analyzing Stock Holders, 4(11), 55-79

Talebi, M.(1995). Knowing cash dimensions and management of in firms. Financial Research Magazines. 11$12,110-126$

Wang, Y. J. (2002). Liquidity management, operating performance, and corporate value: evidence from Japan and Taiwan. Journal of Multinational Financial Management, 12(2), 159-169.

Yalcin, N., Bayrakdaroglu, A., \& Kahraman, C. (2012). Application of fuzzy multi-criteria decision making methods for financial performance evaluation of Turkish manufacturing industries. Expert Systems with Applications, 39(1), 350-364. 